\title{
Dietary Modified Cassava Chip and Corn Seed: Effect on Growth Performance, Rumen Production, and Blood glucose and Insulin in Early Fattening Beef Bulls
}

\author{
Wuttikorn SRAKAEW ${ }^{1}$, Chalong WACHIRAPAKORN ${ }^{1, *}$ and \\ Chantira WONGNEN ${ }^{2}$
}

\author{
${ }^{I}$ Department of Animal Science, Faculty of Agriculture, Khon Kaen University, \\ Khon Kaen 40002, Thailand \\ ${ }^{2}$ School of Agricultural Technology, Walailak University, Nakhon Si Thammarat 80160, Thailand
}

('Corresponding author's e-mail: chal_wch@kku.ac.th)

Received: 8 December 2019, Revised: 9 March 2020, Accepted: 10 April 2020

\begin{abstract}
Effects of feeding modified cassava chip and corn seed as energy source inclusion in diet were investigated on growth performance, rumen fermentation, and blood metabolites in early fattening bulls. Thirty-six 1-year-old Charolais crossbred bulls with initial weight $270 \pm 50 \mathrm{~kg}$ were randomly assigned into 6 groups with different experimental rations as cassava-based concentrates including non-modified cassava chip (Cass-Con), with $15 \%$ of alkaline-treated cassava chip (Cass-Alkaline), with $15 \%$ of steamtreated cassava chip (Cass-Steam) and corn-based concentrates including non-modified corn seed (CornCon), with $15 \%$ of alkaline-treated corn seed (Corn-Alkaline), and with $15 \%$ of steam-treated corn seed (Corn-Steam), according to completely randomized design (CRD). Results showed that feed intake and digestibility were not significantly different among treatments, while digestible dry matter and organic matter intake of Cass-Steam and Corn-Alkaline were higher than those of the other diets $(\mathrm{P}<0.05)$. Ruminal $\mathrm{pH}$ post-feeding was highest in Corn-Alkaline and lowest in Cass-Con $(\mathrm{P}<0.05)$. Blood glucose was similar among treatments. However, blood insulin at $4 \mathrm{~h}$ post-feeding was higher in Cass-Steam, Corn-Alkaline, and Corn-Steam than in the others. Blood insulin in bulls fed corn-based concentrate was higher than in bulls fed cassava-based concentrate $(\mathrm{P}<0.01)$. Body weight gain and average daily gain were significantly higher $(\mathrm{P}<0.05)$, while feed conversion ratio was lower in Cass-Steam, CornAlkaline, and Corn-Steam as compared with in Cass-Con, Cass-Alkaline and Corn-Con. Results indicated that using a modified energy source can improve growth performance in early fattening beef bulls. An appropriate method to modify cassava chip was steam method, while alkaline method for corn seed was superior.
\end{abstract}

Keywords: Modification, Cassava chip, Corn seed, Growth performance, Blood glucose, Insulin, Fattening beef bulls

\section{Introduction}

Starch is the main energy component used in beef cattle feeds due to its availability [1]. In Thailand, starch sources including ground corn and cassava chip are typically used at high ratios in beef cattle diet [2]. Management systems typically encourage the inclusion of high amounts of both starch sources in the diet to support growth performance and fat accumulation. Starch from cassava and corn seed differs in terms of solubility and fermentability in the rumen. Cassava starch has solubility and is rapidly degradable in the rumen at over $90 \%$, while corn starch has low ruminal solubility at $40-60 \%$ [3]. High cassava diets are rapidly fermented, with increasing short chain fatty acid (SCFA) and lactic acid 
http://wjst.wu.ac.th

production accumulation in the rumen causing low $\mathrm{pH}$ with predisposition to rumen acidosis $[4,5]$. By contrast, excess ground corn in the diet causes low starch digestibility, and cattle receive less energy than expectation. Kathrin et al. [6] found that an excess of ruminal non-degradable starch in the diet resulted in low efficiency of ruminal nitrogen utilization and microbial protein synthesis and also decreased starch utilization efficiency [7]. The optimal level of non-degradable starch showed a positive effect on maintaining $\mathrm{pH}$ in the rumen, with increased digestibility and starch flow from the rumen to the small intestine. The starch was subsequently digested by pancreatic enzymes, increasing net absorption of glucose and with a decreased minor loss of energy in the form of methane and heat produced in the rumen [6]. Throckmorton and Lengs [8] found that diet supplementation with optimal by-pass starch level increased live weight gain in cows and directed the energy of unfermented starch in the rumen directly toward live weight gain rather than milk production. Thus, many researchers have attempted to elucidate an appropriate method to modulate the degradability of starch sources in the rumen by enhancing feed efficiency through altering the nature and amount of starch available to rumen microbes and, hence, shifting some starch digestion to the small intestine [9]. Methods to optimize starch flow to the duodenum without reducing rumen fermentability and total tract digestibility are required. Several methods have been used to modify starch structure from grains and tubers, such as application of alkaline and steam approaches. Steam processing improved starch digestion in the rumen [10,11], while treatment with sodium hydroxide $(\mathrm{NaOH})$ was reported to increase starch flow to the duodenum $[9,12]$. However, our previous in vitro study showed different results. We found that modifying cassava starches with steaming and $\mathrm{NaOH}$ treatment decreased ruminal degradability and increased by-pass starch, while non-processed corn resulted in decreased by-pass starch [13]. Different results may depend on grain kernel structure, pericarp of cereal grains, structure of starch (amylose: Amylopectin), and other nutrient contents in the grain (e.g., protein, fat, and fiber) which can bond with starch molecules [14]. We also found that modified cassava chip and corn seed treated with steam and $\mathrm{NaOH}$ had greater ability to modify starch solubility and degradability in the rumen by decreasing the degradability of starch from cassava and increasing the degradability of corn starch. Optimal level in diet at $15-25 \%$ of concentrate did not affect rumen fermentation production and increased growth performance in beef cattle [13]. However, an in vivo study is required to further elucidate these results. Therefore, here, the effects of modified cassava chip and corn seed in diet were determined for rumen fermentation, blood metabolites, and growth performance in early fattening beef bulls.

\section{Materials and methods}

\section{Animal ethics}

The experimental procedure was approved by the Animal Ethics Committee of Khon Kaen University based on the Ethic of Animal Experimentation of the National Research Council of Thailand. Record No. ACUC-KKU-64/60.

\section{Animal and experimental design}

Thirty-six 1-year-old $50 \%$ Charolais and $50 \%$ Thai $\times$ Brahman crossbred bulls $(270 \pm 50 \mathrm{~kg}$ initial body weight; BW) were individually housed in $2 \times 2.5 \mathrm{~m}^{2}$ concrete-floor pens with ambient air ventilation. All animals were dewormed with IVERMECTIN $^{@}(2.5 \mathrm{~mL} /$ heads $)$, injected with a multiple vitamin including $\mathrm{A}, \mathrm{D}$, and $\mathrm{E}$ with a commercial dosage $(3 \mathrm{~mL} / \mathrm{heads})$, and received FMD vaccinations before being submitted to a 21-day adaptation period to experimental facilities, handling, and diets, in which animals received 3 step-up diets containing increasing levels of concentrate, and to a 90-day early fattening period. The animals were divided into 6 groups, with each group containing 6 bulls, and randomly assigned to 1 of 6 experimental rations according to completely randomized design (CRD). Animals were fed twice daily with drinking water ad libitum.

\section{Feed preparation}

All corn seed and cassava chip were delivered to the laboratory form animal feed factory of Khon Kaen University in the same lot. The steam method was modified from [15]. Whole corn seed and 
cassava chip were soaked in water for $12 \mathrm{~h}$ to increase moisture content before steaming in a 2 tiered steam pot $\left(20 \times 80 \mathrm{~cm}^{2}\right.$ of high $\times$ diameter of pot size $)$ for $45 \mathrm{~min}$ at $150{ }^{\circ} \mathrm{C}$, and then spread on a carpet in natural sun conditions until dry. The alkaline method was modified from De Campeneere et al. [16]. Both corn seed and cassava chip were treated with $\mathrm{NaOH}$ solution applied at $3.5 \%$ (wt/vol) with water. The $\mathrm{NaOH}$ solution was then mixed with the ingredients at ratio 1:1 (vol/wt) in large buckets and left uncovered for $24 \mathrm{~h}$. The mixed ingredients and residual $\mathrm{NaOH}$ were spread on a carpet in natural sun conditions until dry. Both modified corn seed and cassava chip were ground to the same particle size to pass through a $4 \mathrm{~mm}$ sieve screen before being mixed in the concentrate.

\section{Experimental feed and feeding}

All concentrates were formulated with similar crude protein $(18 \% \mathrm{CP})$ and metabolizable energy (2.70 Mcal ME/kg DM) (Tables 1 and 2). Animals were fed the diets as a separated feed twice daily $(08.00$ am and $05.00 \mathrm{pm})$, with concentrate offered at $1.5 \%$ of body weight $(\mathrm{BW})$ and rice straw as roughage source ad libitum. Experimental diets were categorized as T1; cassava-based concentrate without modified cassava chip (Cass-Con), T2; cassava-based concentrate with $15 \%$ alkaline-treated cassava chip (Cass-Alkaline), T3; cassava-based concentrate with $15 \%$ steam-treated cassava chip (CassSteam), T4; corn-based concentrate without modified corn seed (Corn-Con), T5; corn-based concentrate with $15 \%$ alkaline-treated corn seed (Corn-Alkaline), and T6; corn-based concentrate with $15 \%$ steamtreated corn seed (Corn-Steam).

Table 1 Percentage of feed ingredients of experimental diets.

\begin{tabular}{|c|c|c|c|c|c|c|}
\hline \multirow[b]{2}{*}{ Items } & T1 & $\mathbf{T 2}$ & T3 & T4 & T5 & T6 \\
\hline & \multicolumn{6}{|c|}{$\mathrm{kg} / 100 \mathrm{~kg}$} \\
\hline Cassava chip & 57.0 & 42.0 & 42.0 & 26.0 & 26.0 & 26.0 \\
\hline Alkaline-treated cassava chip & - & 15.0 & - & - & - & - \\
\hline Steam-treated cassava chip & - & - & 15.0 & - & - & - \\
\hline Ground corn & - & - & - & 40.0 & 25.0 & 25.0 \\
\hline Alkaline-treated corn seed & - & - & - & - & 15.0 & - \\
\hline Steam-treated corn seed & - & - & - & - & - & 15.0 \\
\hline Rice brand & 8.50 & 8.50 & 8.50 & 8.50 & 8.50 & 8.50 \\
\hline Soybean meal & 15.0 & 15.0 & 15.0 & 13.5 & 13.5 & 13.5 \\
\hline Palm kernel meal & 14.0 & 14.0 & 14.0 & 7.00 & 7.00 & 7.00 \\
\hline Salt & 0.40 & 0.40 & 0.40 & 0.40 & 0.40 & 0.40 \\
\hline Dicalcium phosphate & 1.50 & 1.50 & 1.50 & 1.50 & 1.50 & 1.50 \\
\hline Premixed & 0.50 & 0.50 & 0.50 & 0.50 & 0.50 & 0.50 \\
\hline Sulfur & 0.30 & 0.30 & 0.30 & 0.30 & 0.30 & 0.30 \\
\hline Molasses & 1.50 & 1.50 & 1.50 & 1.50 & 1.50 & 1.50 \\
\hline Urea & 1.30 & 1.30 & 1.30 & 0.80 & 0.80 & 0.80 \\
\hline Total & 100.0 & 100.0 & 100.0 & 100.0 & 100.0 & 100.0 \\
\hline
\end{tabular}

$\mathrm{T} 1=$ cassava-based concentrate without modified cassava chip (Cass-Con), $\mathrm{T} 2$ = cassava-based concentrate with $15 \%$ of alkaline-treated cassava chip (Cass-Alkaline), T3 = cassava-based concentrate with $15 \%$ of steam-treated cassava chip (Cass-Steam), T4 = corn-based concentrate without modified corn seed (Corn-Con), T5 = corn-based concentrate with $15 \%$ of alkaline-treated corn seed (CornAlkaline), and T6 = corn-based concentrate with $15 \%$ of steam-treated corn seed (Corn-Steam). 
http://wjst.wu.ac.th

Table 2 Chemical composition of experimental diets.

\begin{tabular}{|c|c|c|c|c|c|c|c|}
\hline Items & $\mathrm{T1}^{1}$ & $\mathbf{T 2}$ & T3 & T4 & T5 & T6 & Rice straw \\
\hline \multirow[t]{2}{*}{ Dry matter, $\%$} & 90.2 & 91.1 & 89.9 & 90.1 & 90.4 & 90.6 & 89.7 \\
\hline & \multicolumn{7}{|c|}{ - } \\
\hline Organic matter & 93.4 & 92.9 & 94.1 & 94.9 & 94.7 & 94.7 & 88.2 \\
\hline Crude protein & 18.3 & 18.0 & 17.9 & 18.0 & 17.9 & 17.9 & 3.3 \\
\hline Ether extract & 5.7 & 5.9 & 5.9 & 5.1 & 5.5 & 5.6 & 0.6 \\
\hline Crude fiber & 11.6 & 10.3 & 6.5 & 5.7 & 7.56 & 7.21 & 47.1 \\
\hline $\mathrm{NFE}^{2}$ & 57.8 & 58.6 & 63.8 & 66.1 & 63.7 & 63.9 & 37.2 \\
\hline $\mathrm{NDF}^{2}$ & 40.1 & 44.2 & 37.3 & 45.3 & 39.0 & 38.8 & 81.1 \\
\hline $\mathrm{ADF}^{2}$ & 14.5 & 12.9 & 8.13 & 7.14 & 9.45 & 9.01 & 57.7 \\
\hline Ash & 6.57 & 7.11 & 5.90 & 5.05 & 5.31 & 5.32 & 11.8 \\
\hline $\mathrm{ME}^{3}, \mathrm{Mcal} / \mathrm{kgDM}$ & 2.65 & 2.68 & 2.78 & 2.78 & 2.73 & 2.76 & 1.46 \\
\hline
\end{tabular}

${ }^{\mathrm{I}}$ See Table 1

${ }^{2} \mathrm{NFE}=$ nitrogen free extract, $\mathrm{DF}=$ Neutral Detergent Fiber, ADF $=$ Acid Detergent Fiber

${ }^{3}$ Calculated according to Harris et al. [17]

$\mathrm{ME}$ in $\mathrm{Mcal} / \mathrm{kg}=\mathrm{DE}(\mathrm{Mcal} / \mathrm{kg}) \times 0.82$

$\mathrm{DE}$ is using the factor of $4.41 \mathrm{Mcal} / \mathrm{kg} \mathrm{TDN}$

for concentrate TDN $(\%$ of DM $)=40.2625+0.1969(\% \mathrm{CP})+0.4228(\% \mathrm{NFE})+1.1903(\% \mathrm{EE})-0.1379(\% \mathrm{CF})$

for rice straw TDN $(\%$ of DM $)=-7.2649+1.2120(\% \mathrm{CP})+0.8352(\% \mathrm{NFE})+2.4637(\% \mathrm{EE})+0.4475(\% \mathrm{CF})$

\section{Body weight gain and performance measurement}

Animals were weighed in the early morning at the beginning of every month during the experimental period to determine BW gain and average daily gain (ADG). Feed intake was adjusted monthly to be used as a concentrate feeding guideline for the beef bulls. Feeding volume and feed refusal were recorded at 8:00 am daily to calculate individual feed intake and feed conversion ratio during the early fattening period.

\section{Sample collection and analysis}

Experimental concentrate and rice straw formulae were sampled every 30 days. Fecal samples were collected during the last 7 days of the finishing period by rectal sampling. Samples of diets and feces of each collection time were pooled before drying at $60^{\circ} \mathrm{C}$ for $72 \mathrm{~h}$ and then analyzed for dry matter (DM), ether extract (EE), ash and CP contents [18], fiber fractions, such as neutral detergent fiber (NDF), and acid detergent fiber (ADF) [19]. Acid insoluble ash (AIA) was analyzed and used to calculate the apparent digestibility of nutrients [20].

At the end of the experiment, rumen fluid and jugular blood samples were collected at 0 and $4 \mathrm{~h}$ post-morning feeding. Ruminal fluid samples (approximately $500 \mathrm{~mL}$ ) were collected by a stomach tube. The $\mathrm{pH}$ of the ruminal fluid was immediately measured using a portable $\mathrm{pH}$ meter. Samples of rumen fluid were filtered through four layers of cheesecloth and then $100 \mathrm{~mL}$ of filtrated rumen fluid was mixed with $10 \mathrm{~mL}$ of $50 \%$ sulfuric acid $\left(\mathrm{H}_{2} \mathrm{SO}_{4}\right)$ solution and used for ammonia-nitrogen $\left(\mathrm{NH}_{3}-\mathrm{N}\right)$ and volatile fatty acid (VFA) analyses. The mixed sample was centrifuged at $16,000 \times \mathrm{g}$ for $15 \mathrm{~min}$ and the supernatant was stored at $-20{ }^{\circ} \mathrm{C}$ prior to $\mathrm{NH}_{3}-\mathrm{N}$ measurement, according to the method of Bremner and Keeney [21], and VFA analysis using HPLC (model RF-10AXmugiL; Shimadzu; Japan) [22]. Samples of blood were drawn from the jugular vein into two tubes (about $10 \mathrm{~mL} /$ tube). The $1^{\text {st }}$ tube was separated by centrifugation at $500 \times \mathrm{g}$ for $10 \mathrm{~min}$ and stored at $-20{ }^{\circ} \mathrm{C}$ until analysis of blood urea nitrogen (BUN), according to the method of Crocker [23]. The $2^{\text {nd }}$ blood tube was used to measure blood metabolites such as glucose and insulin at Thonburi Lab Center Co., Ltd. 


\section{Statistical analysis}

All obtained data were subjected to the Analysis of Variance (ANOVA) procedures of SAS [24] according to a CRD design. Data were analyzed using the model $\mathrm{Yij}=\mu+\mathrm{Mi}+\varepsilon \mathrm{ij}$, where $\mathrm{Yij}=$ observation from animal $\mathrm{j}$, receiving diet $\mathrm{i} ; \mu=$ the overall of mean, $\mathrm{Mi}=$ the mean effect of treatment $(\mathrm{i}=1,2,3,4,5,6), \varepsilon \mathrm{ij}=$ the residual effect. Means were statistically compared using Duncan's New Multiple Range Test (DMRT) [25].

\section{Results and discussion}

\section{Feed intake and nutrient digestibility}

No difference among dietary treatments was observed concerning intake of concentrate, rice straw, and total feed $(\mathrm{P}>0.05)$ (Table 3). Total feed intake averaged $2.37-2.55 \% \mathrm{BW}$ and related to normal guidelines for feeding beef cattle weighing $250-350 \mathrm{~kg}$ as recommended average feed intake at $2.5 \%$ BW [26]. Schmidt et al. [27] reported that steers with average initial weight of $320 \pm 20 \mathrm{~kg}$ consumed diet at about $2.45 \%$ BW. Apparent digestibility of DM, organic matter (OM), CP, EE, NDF, and ADF were not significantly different among treatments $(\mathrm{P}>0.05)$. Digestibility of $\mathrm{CP}$ was influenced by starch sources which increased in dietary corn-based concentrate compared to dietary cassava-based concentrate $(\mathrm{P}<0.05)$.

However, apparent OM digestibility (OMD) was influenced by adding modified starch. Diets containing modified starches showed higher OMD than the non-modified starch diets $(\mathrm{P}<0.05)$. Starch caused gelatinization (intermolecular disruption of hydrogen bonds) during alkaline or steam treatment and enhanced the surface of the corn kernel, available for microbial attachment, resulting in greater ruminal digestion of starch related with high OMD [28]. Moreover, diets containing modified cassava and corn showed higher rumen $\mathrm{pH}$ at $4 \mathrm{~h}$ post-feeding, with more stable values than diets containing nonmodified starch (Table 4). Observed $\mathrm{pH}$ was reported as optimal for microbial digestion of fiber [29] and also digestion of protein in the rumen [30].

Table 3 Effects of dietary modified cassava and corn on voluntary feed intake and digestibility.

\begin{tabular}{|c|c|c|c|c|c|c|c|c|c|c|c|}
\hline \multirow[b]{2}{*}{ Items } & \multicolumn{6}{|c|}{ Treatments } & \multirow[b]{2}{*}{ SEM } & \multicolumn{4}{|c|}{ Contrast } \\
\hline & $T 1^{1}$ & $\mathbf{T 2}$ & T3 & $\mathrm{T} 4$ & T5 & T6 & & $\begin{array}{l}\text { T1,2,3: } \\
\text { T4,5,6 }\end{array}$ & $\begin{array}{c}\text { T1,4: } \\
\text { T2,3,5,6 }\end{array}$ & T2:T3 & T5:T6 \\
\hline \multicolumn{12}{|c|}{ Feed intake (kg, DM) } \\
\hline Concentrate & 5.02 & 5.08 & 5.23 & 5.07 & 5.17 & 4.93 & 0.13 & 0.84 & 0.74 & 0.63 & 0.15 \\
\hline Rice straw & 3.25 & 3.09 & 3.31 & 3.15 & 3.28 & 3.16 & 0.07 & 0.95 & 0.93 & 0.06 & 0.16 \\
\hline Total & 8.27 & 8.18 & 8.54 & 8.22 & 8.45 & 8.09 & 0.17 & 0.86 & 0.80 & 0.27 & 0.12 \\
\hline$\%$ of $\mathrm{BW}$ & 2.49 & 2.37 & 2.45 & 2.53 & 2.55 & 2.47 & 0.07 & 0.17 & 0.55 & 0.43 & 0.42 \\
\hline \multicolumn{12}{|c|}{ Apparent digestibility (\%) } \\
\hline $\mathrm{DM}$ & 64.0 & 66.0 & 67.9 & 67.6 & 67.6 & 67.6 & 1.85 & 0.35 & 0.30 & 0.57 & 0.99 \\
\hline $\mathrm{OM}$ & 67.4 & 70.6 & 72.6 & 70.9 & 71.4 & 72.4 & 1.67 & 0.48 & 0.05 & 0.48 & 0.68 \\
\hline $\mathrm{CP}$ & 73.8 & 74.1 & 75.8 & 76.2 & 76.2 & 77.4 & 1.33 & 0.05 & 0.36 & 0.41 & 0.49 \\
\hline $\mathrm{EE}$ & 81.1 & 80.1 & 82.2 & 84.9 & 81.1 & 80.5 & 1.68 & 0.53 & 0.20 & 0.42 & 0.77 \\
\hline $\mathrm{NDF}$ & 59.4 & 63.3 & 62.5 & 66.4 & 63.7 & 62.5 & 1.47 & 0.07 & 0.97 & 0.66 & 0.62 \\
\hline $\mathrm{ADF}$ & 42.0 & 46.7 & 40.1 & 41.6 & 48.6 & 44.2 & 2.90 & 0.51 & 0.30 & 0.23 & 0.34 \\
\hline \multicolumn{12}{|c|}{ Digestible nutrient intake (kg/day) } \\
\hline $\mathrm{DM}$ & $5.29^{\mathrm{c}}$ & $5.40^{\mathrm{bc}}$ & $5.80^{\mathrm{a}}$ & $5.56^{\mathrm{b}}$ & $5.71^{\mathrm{ab}}$ & $5.47^{\mathrm{bc}}$ & 0.07 & 0.37 & 0.01 & 0.01 & 0.03 \\
\hline OM & $5.09^{\mathrm{b}}$ & $5.26^{\mathrm{ab}}$ & $5.69^{\mathrm{a}}$ & $5.38^{\mathrm{ab}}$ & $5.55^{\mathrm{a}}$ & $5.39^{\mathrm{ab}}$ & 0.12 & 0.52 & 0.03 & 0.05 & 0.47 \\
\hline
\end{tabular}


http://wjst.wu.ac.th

\begin{tabular}{|c|c|c|c|c|c|c|c|c|c|c|c|}
\hline \multirow[b]{2}{*}{ Items } & \multicolumn{6}{|c|}{ Treatments } & \multirow[b]{2}{*}{ SEM } & \multicolumn{4}{|c|}{ Contrast } \\
\hline & $\mathbf{T} 1^{1}$ & $\mathbf{T} 2$ & T3 & T4 & T5 & T6 & & $\begin{array}{r}\text { T1,2,3: } \\
\text { T4,5,6 }\end{array}$ & $\begin{array}{c}T 1,4: \\
T 2,3,5,6\end{array}$ & T2:T3 & T5:T6 \\
\hline $\mathrm{CP}$ & 0.76 & 0.75 & 0.79 & 0.77 & 0.79 & 0.77 & 0.04 & 0.11 & 0.28 & 0.24 & 0.31 \\
\hline $\mathrm{EE}$ & 0.25 & 0.26 & 0.27 & 0.24 & 0.25 & 0.24 & 0.04 & 0.09 & 0.14 & 0.86 & 0.26 \\
\hline NDF & 2.76 & 3.01 & 2.89 & 3.21 & 2.97 & 2.80 & 0.15 & 0.07 & 0.22 & 0.28 & 0.13 \\
\hline $\mathrm{ADF}$ & 1.01 & 1.14 & 0.94 & 0.91 & 1.16 & 1.00 & 0.03 & 0.58 & 0.43 & 0.12 & 0.16 \\
\hline \multicolumn{12}{|c|}{ Metabolizable energy intake, Mcal/d } \\
\hline & $19.3^{b}$ & $20.0^{\mathrm{ab}}$ & $21.6^{\mathrm{a}}$ & $20.4^{\mathrm{ab}}$ & $21.1^{\mathrm{a}}$ & $20.5^{\mathrm{ab}}$ & 0.40 & 0.53 & 0.04 & 0.06 & 0.46 \\
\hline
\end{tabular}

${ }^{\mathrm{abc}}$ Values in the same row with different superscripts differ $(\mathrm{p}<0.05)$

${ }^{1}$ See Table 1

Nevertheless, digestible DM and OM intake $(\mathrm{P}<0.05)$ were highest in Cass-Steam and CornAlkaline (Table 3), while digestible CP, EE, NDF, and ADF intake were not significantly different among dietary treatments $(\mathrm{P}>0.05)$. Higher DMD and OMD intake in Cass-Steam and Corn-Alkaline $(\mathrm{P}<0.05)$ were related to higher intake of energy, as shown in Table 3. Growth performance of fattening bulls observed here met energy requirements for gain, as reported by Br-Corte [31].

\section{Rumen fermentation products}

Ruminal $\mathrm{pH}$ values in all treatments before morning feeding were high and similar $(\mathrm{P}>0.05)$, while values decreased at $4 \mathrm{~h}$ post-feeding (Table 4). Ruminal $\mathrm{pH}$ value remained high in Corn-Alkaline and slightly decreased in Corn-Steam, Corn-Con, Cass-Alkaline, and Cass-Steam, with lowest value in CassCon $(\mathrm{P}<0.05)$ By comparison, bulls fed a diet including corn had higher ruminal $\mathrm{pH}$ value than those fed cassava diets $(\mathrm{P}<0.05)$. The modified starch diet maintained high $\mathrm{pH}$ compared with non-modified diets $(\mathrm{P}<0.05)$. Rumen $\mathrm{pH}$ ranged 6.58- 7.08 and in the normal range of rumen ecology ( $\mathrm{pH} 6.2-7.0$ ), reported as optimal for microbial fermentation [32]. Reduction of ruminal $\mathrm{pH}$ found in Cass-Con treatment may be explained by higher degradation in the rumen of cassava chip than corn seed and all modified diets of corn seed and cassava chip. Similarly, Gulmez and Turkmen [33] observed a decrease of ruminal $\mathrm{pH}$ in lactating cows when corn was replaced by wheat. Generally, cassava is a fermentable energy source in ruminant feed, with a high rate and extent of ruminal degradation [34]. Sommart et al. [3] reported that rate of ruminal degradation of starch from cassava was higher than corn and broken rice, while Huntington [35] reported that percentage intakes of rumen degradable starch by the in situ method of corn, wheat, and cassava were 49.5, 88.3, and $94.0 \%$, respectively. Ruminal degradability of starch varied with different sources of grain [3]. Bulls fed diets with modified starch showed slightly higher rumen $\mathrm{pH}$ than normal diets, influenced by increasing the portion of rumen-undegradable starch in diets $(\mathrm{P}<0.05)$. Kathrin et al. [6] reported that slow-fermented diet in the rumen results in low product of short-chain fatty acids (SCFA) and higher ruminal $\mathrm{pH}$.

Rumen fermentation end-products, including total VFAs, acetate (C2), propionate (C3), and butyrate $(\mathrm{C} 4)$ concentration, $\mathrm{C} 2: \mathrm{C} 3$ ratio, rumen $\mathrm{NH}_{3}-\mathrm{N}$, and $\mathrm{BUN}$ were not significantly different among dietary treatments $(\mathrm{P}>0.05)$. Yang et al. [36] found that increasing the level of by-pass starch from 12.1 to $33 \%$ in goat feed showed no effect on production of $\mathrm{C} 2, \mathrm{C} 3$, and $\mathrm{C} 4$, while McNiven et al. [37] showed that feeding dairy cows with $\mathrm{NaOH}$ treated barley diets did not affect VFA production. However, Ørskov and Reid [38] found that $\mathrm{C} 2$ to $\mathrm{C} 3$ ratio was greatest for cows fed $\mathrm{NaOH}$-treated barley. According to our observed data, although $\mathrm{C} 2: \mathrm{C} 3$ ratio was not significant different among treatments, $\mathrm{C} 2: \mathrm{C} 3$ ratio at $4 \mathrm{~h}$ post feeding tended to be lower when beef bulls were fed modified starch diets $(\mathrm{P}=$ $0.09)$. The $\mathrm{NH}_{3}-\mathrm{N}$ values in this experiment ranged in the optimal level $(15-30 \mathrm{mg} \%)$ to support microbial protein synthesis and to optimize ruminal feed digestibility [30]. 
Table 4 Effects of dietary modified cassava and corn on ruminal production and blood metabolites.

\begin{tabular}{|c|c|c|c|c|c|c|c|c|c|c|c|}
\hline \multirow[b]{2}{*}{ Items } & \multicolumn{6}{|c|}{ Treatments } & \multirow[b]{2}{*}{ SEM } & \multicolumn{4}{|c|}{ Contrast } \\
\hline & $\mathrm{T1}^{1}$ & $\mathbf{T} 2$ & T3 & T4 & T5 & T6 & & $\begin{array}{l}\text { T1,2,3: } \\
\text { T4,5,6 }\end{array}$ & $\begin{array}{c}\text { T1,4: } \\
\text { T2,3,5,6 }\end{array}$ & T2:T3 & T5:T6 \\
\hline \multicolumn{12}{|c|}{ Ruminal fermentation products and blood metabolites, $0 \mathrm{~h}$ post-feeding } \\
\hline Rumen $\mathrm{pH}$ & 7.07 & 7.04 & 7.06 & 7.04 & 7.08 & 7.05 & 0.04 & 0.84 & 0.98 & 0.77 & 0.63 \\
\hline $\begin{array}{l}\text { Rumen } \mathrm{NH}_{3} \text {, } \\
\mathrm{mg} / \mathrm{dL}\end{array}$ & 13.1 & 11.3 & 12.2 & 14.0 & 12.2 & 15.7 & 1.86 & 0.39 & 0.76 & 0.80 & 0.32 \\
\hline \multicolumn{12}{|c|}{ Ruminal VFA production, $\%$ of total } \\
\hline $\mathrm{C} 2$ & 68.0 & 69.2 & 69.1 & 68.3 & 70.1 & 66.9 & 1.09 & 0.79 & 0.60 & 0.94 & 0.13 \\
\hline $\mathrm{C} 3$ & 20.4 & 20.8 & 20.9 & 21.5 & 18.8 & 21.8 & 0.87 & 0.99 & 0.70 & 0.96 & 0.08 \\
\hline $\mathrm{C} 4$ & 11.6 & 9.98 & 10.1 & 10.2 & 11.1 & 11.3 & 0.59 & 0.63 & 0.67 & 0.94 & 0.89 \\
\hline $\mathrm{C} 2: \mathrm{C} 3$ ratio & 3.33 & 3.32 & 3.31 & 3.17 & 3.69 & 3.10 & 0.64 & 0.22 & 0.12 & 0.69 & 0.10 \\
\hline Total, mg/100 mL & 117.9 & 123.0 & 122.6 & 122.2 & 121.0 & 116.1 & 3.98 & 0.83 & 0.76 & 0.95 & 0.58 \\
\hline BUN, mg/dL & 9.00 & 13.0 & 12.3 & 10.6 & 9.60 & 9.00 & 1.23 & 0.22 & 0.41 & 0.77 & 0.77 \\
\hline \multicolumn{12}{|c|}{ Ruminal fermentation products and blood metabolite, $4 \mathrm{~h}$ post feeding } \\
\hline Rumen $\mathrm{pH}$ & $6.58^{\mathrm{b}}$ & $6.77^{\mathrm{ab}}$ & $6.75^{\mathrm{ab}}$ & $6.80^{\mathrm{ab}}$ & $6.92^{\mathrm{a}}$ & $6.82^{\mathrm{ab}}$ & 0.06 & 0.03 & 0.04 & 0.78 & 0.11 \\
\hline $\begin{array}{l}\text { Rumen } \mathrm{NH}_{3} \text {, } \\
\mathrm{mg} / \mathrm{dL}\end{array}$ & 20.1 & 17.5 & 22.6 & 18.3 & 17.4 & 17.5 & 1.64 & 0.21 & 0.80 & 0.11 & 0.99 \\
\hline \multicolumn{12}{|c|}{ Ruminal VFA production, $\%$ of total } \\
\hline $\mathrm{C} 2$ & 69.7 & 68.1 & 66.7 & 69.2 & 67.8 & 68.0 & 1.14 & 0.88 & 0.17 & 0.51 & 0.93 \\
\hline $\mathrm{C} 3$ & 20.7 & 22.0 & 23.4 & 21.7 & 22.8 & 22.2 & 0.87 & 0.83 & 0.17 & 0.37 & 0.70 \\
\hline $\mathrm{C} 4$ & 9.51 & 9.84 & 9.77 & 8.90 & 9.29 & 9.74 & 0.54 & 0.56 & 0.53 & 0.95 & 0.68 \\
\hline $\mathrm{C} 2: \mathrm{C} 3$ ratio & 3.36 & 3.09 & 2.85 & 3.18 & 2.97 & 3.06 & 0.36 & 0.47 & 0.09 & 0.31 & 0.12 \\
\hline Total, mg/100 mL & 131.4 & 127.8 & 130.4 & 136.5 & 132.5 & 128.4 & 7.79 & 0.76 & 0.64 & 0.85 & 0.77 \\
\hline BUN, mg/dL & 9.30 & 13.7 & 15.3 & 12.0 & 12.3 & 10.0 & 1.40 & 0.38 & 0.49 & 0.52 & 0.38 \\
\hline
\end{tabular}

abc Values in the same row with different superscripts differ $(\mathrm{p}<0.05)$.

See Table 1

\section{Blood glucose and insulin}

Concentrations of blood glucose and insulin are shown in Figure 1. Blood glucose was not affected by dietary treatments $(\mathrm{P}>0.05)$. Glucose level in the blood prior to feeding was slightly lower than in blood at $4 \mathrm{~h}$ post-feeding. According to Wasserman [39], glucose levels are usually lowest in the morning before the $1^{\text {st }}$ feed of the day and, thereafter, rise every hour or two by a few millimoles. Glucose concentrate values in all dietary treatments were within the normal range of 45 to $75 \mathrm{mg} / \mathrm{dL}$ [40]. Glucose is stored in skeletal muscle and liver cells in the form of glycogen [41]. Cellular glucose uptake is primarily regulated by insulin, a hormone produced in the pancreas. Hormone regulation is most important. There are 2 types of mutually antagonistic metabolic hormones affecting blood glucose levels: catabolic hormones (such as glucagon, cortisol, and catecholamines) which increase blood glucose [42], and an anabolic hormone (insulin) which decreases blood glucose. Glucose levels in the blood are usually within the normal range. If glucose levels stray out of this range, amounts of insulin and glucagon produced by the pancreas adjust to bring glucose levels back into normal range [41]. In this study, blood insulin levels at $4 \mathrm{~h}$ after morning feeding increased in beef cattle fed Cass-Steam, Corn-Alkaline, and Corn-Steam $(\mathrm{P}<0.01)$, and levels were influenced by starch sources and modified methods $(\mathrm{P}<0.01)$. Beef bulls fed corn-based diets had higher insulin levels than those fed cassava-based diets, while modified starches showed increased insulin concentration in blood compared with non-modified starches. These results indicated that the concentration of glucose absorbed across gut epithelial cells to the blood may increase in treatments of high blood insulin, but levels of glucose in the blood were not significantly different, owing to homeostasis, which decreased blood glucose to bring glucose levels back into normal range by insulin [41]. Thus, increasing concentration of insulin in the blood may result in beef bulls fed 
http://wjst.wu.ac.th

modified corn seed or cassava chip having more bypass energy to the small intestine. This is then digested by pancreatic enzymes and directly absorbed as glucose [43].

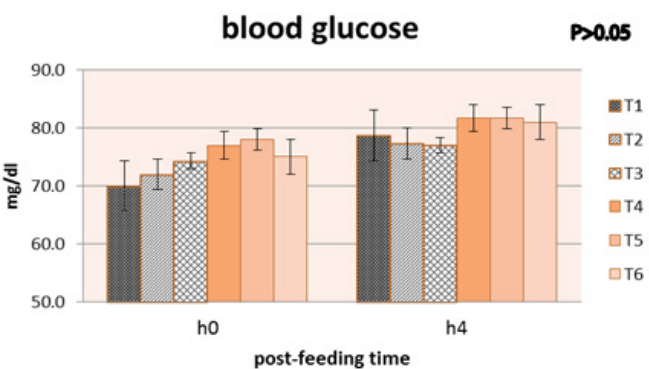

a

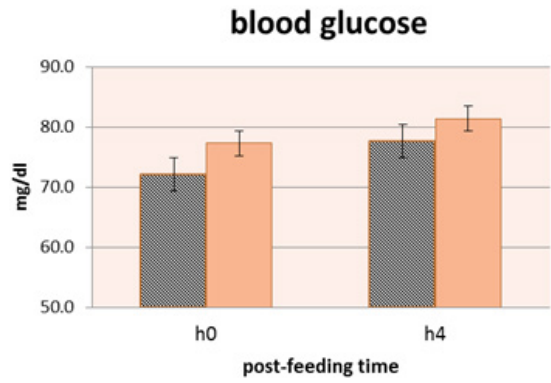

c

blood glucose

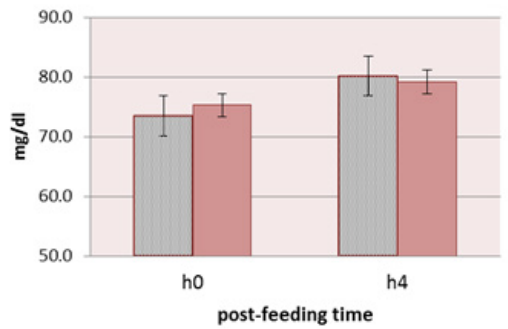

e

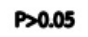

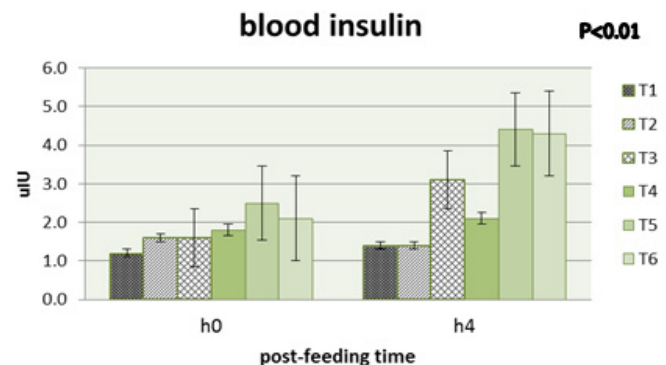

b

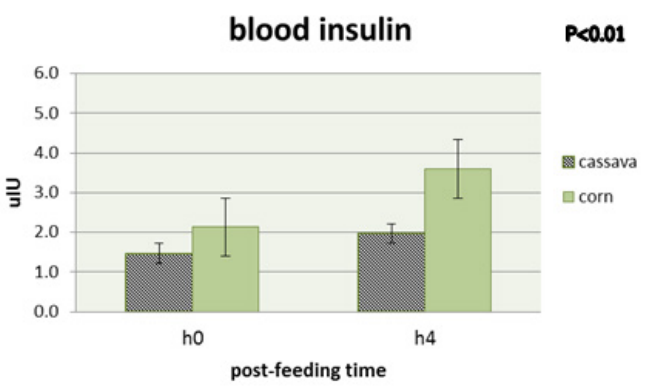

$d$

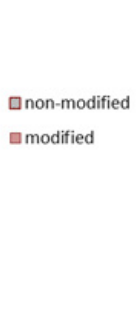

blood insulin

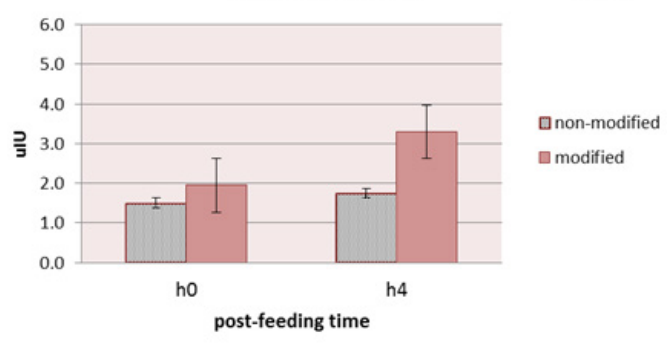

f

Figure 1 Effects of using modified cassava and corn in diets on blood glucose and insulin in beef bulls. a) blood glucose in all treatments, b) blood insulin in all treatments, c) blood glucose compared between cassava and corn diets, d) blood insulin compared between cassava and corn diets, e) blood glucose compared between modified and non-modified starch diets, f) blood insulin compared between modified and non-modified starch diets

\section{Body weight changes and feed conversion ratio}

Animal performances during the experimental period are shown in Table 5. Significant differences were shown among treatments $(\mathrm{P}<0.05)$. BW gain and ADG were significantly higher in Corn-Alkaline and Corn-Steam diets, and slightly higher in Cass-Steam and Corn-Con diets, compared with Cass-Con and Cass-Alkaline $(\mathrm{P}<0.05)$. Moreover, bulls fed diets containing corn-based concentrates had higher BW gain and ADG than those fed cassava-based concentrates $(\mathrm{P}<0.01)$. Bulls fed Cass-Steam and CornAlkaline diets showed highest BW gain and ADG, with lowest feed concentration ratio (FCR) of cassava- 
based concentrate and corn-based concentrate, respectively $(\mathrm{P}<0.05)$. The FCR exhibited a strong decrease when the bulls received Corn-Alkaline diet and slightly low in Cass Steam, Corn-Steam, and Corn-Con diets compared with Cass-Con and Cass-Alkaline diets $(\mathrm{P}<0.05)$. However, there was no significant difference between the efficiency of feed-conversion for body weight gain of non-modified and modified diet animals $(\mathrm{P}>0.05)$.

Several previous studies found similar growth performances when comparing corn and cassava as energy sources in diet [44]. Addition of modified cassava chip or corn seed to the diet may decrease the rate of starch fermentation, causing a stable high rumen $\mathrm{pH}$ value. Ground corn is a great source of energy due to its high carbohydrate and protein content compared with cassava chip. However, methods used for modifying corn can change ruminal starch availability [45]. When compared with intact corn seed, steam processed corn was more digestible due to changes in the structure of starch granules following exposure to a combination of moisture and heat. As a result, using steamed corn increased starch utilization and released higher energy available for production to the cow [45]. Cereal grain treated with $\mathrm{NaOH}$ inclusion in dairy cow diets increased milk production [16] but had no effect on milk yield or milk composition for cows fed $\mathrm{NaOH}$ treated barley [46]. Throckmorton and Lengs [8] found that diet supplementation with modified by-pass starch increased live weight gain and directed the energy of starch escaping rumen fermentation directed toward live weight gain rather than milk production.

Table 5 Effects of dietary modified cassava and corn on growth performance.

\begin{tabular}{|c|c|c|c|c|c|c|c|c|c|c|c|}
\hline \multirow[b]{2}{*}{ Items } & \multicolumn{6}{|c|}{ Treatments } & \multirow{2}{*}{ SEM } & \multicolumn{4}{|c|}{ Contrast } \\
\hline & $\mathbf{T 1}^{1}$ & $\mathbf{T 2}$ & T3 & T4 & T5 & T6 & & $\begin{array}{l}\text { T1,2,3: } \\
\text { T4,5,6 } \\
\end{array}$ & $\begin{array}{c}\text { T1,4:T2, } \\
3,5,6 \\
\end{array}$ & T2:T3 & T5:T6 \\
\hline Initial weight (kg) & 278.6 & 278.8 & 286.3 & 274.8 & 269.6 & 287.3 & - & - & - & - & - \\
\hline Final weight (kg) & 381.0 & 382.0 & 412.8 & 387.5 & 408.0 & 410.0 & - & - & - & - & - \\
\hline Weight gain $(\mathrm{kg})$ & $102.4^{\mathrm{c}}$ & $103.3^{\mathrm{c}}$ & $126.5^{\mathrm{ab}}$ & $112.8^{\mathrm{bc}}$ & $138.3^{\mathrm{a}}$ & $123.0^{\mathrm{ab}}$ & 6.92 & 0.01 & 0.05 & 0.09 & 0.02 \\
\hline ADG (kg/day) & $1.09^{\mathrm{c}}$ & $1.10^{\mathrm{c}}$ & $1.35^{\mathrm{ab}}$ & $1.20^{\mathrm{bc}}$ & $1.47^{\mathrm{a}}$ & $1.31^{\mathrm{ab}}$ & 0.07 & 0.01 & 0.05 & 0.09 & 0.02 \\
\hline FCR & $7.58^{\mathrm{c}}$ & $7.44^{\mathrm{c}}$ & $6.35^{\mathrm{ab}}$ & $6.85^{\mathrm{b}}$ & $5.97^{\mathrm{a}}$ & $6.17^{\mathrm{ab}}$ & 0.27 & 0.21 & 0.61 & 0.16 & 0.41 \\
\hline
\end{tabular}

${ }^{a b c}$ Values in the same row with different superscripts differ $(\mathrm{p}<0.05)$.

${ }^{1}$ See Table 1

\section{Conclusions}

The results from the present study are interpreted to suggest that using modified cassava chip and corn seed incorporated in concentrate at $15 \%$ can be used to improve feed utilization, rumen fermentation, body weight gain, and average daily gain of Charolais $\times$ Brahman crossbred bulls in developing tropical countries. Furthermore, our results indicate that cassava chip modified by the steam method and corn seed modified by the alkaline method were suitable for increasing bypass energy in early fattening bull diets. 


\section{Acknowledgements}

The authors would like to express heartfelt thanks to the Royal Golden Jubilee (RGJ) Ph.D. program, the Agricultural Research Development Agency (ARDA), and the Increase Production Efficiency and Meat Quality of Native Beef and Buffalo Research Group, Khon Kaen University, Thailand, for financial support. We would also like to express our sincere thanks to the Department of Animal Science, Faculty of Agriculture, Khon Kaen University, Thailand, for facilities support.

\section{References}

[1] MSM Marcela and F Granados-Chinchilla. Total starch in animal feeds and silages based on the chromatographic determination of glucose. Methods $X$ 2018; 5, 83-9.

[2] R Pilachai, JTh Schonewille, C Thamrongyoswittayakul, S Aiumlamai, C Wachirapakorn, H Everts and WH Hendriks. The effects of high levels of rumen degradable protein on rumen $\mathrm{pH}$ and histamine concentrations in dairy cows. J. Anim. Physiol. Anim. Nutr. 2012; 96, 206-13.

[3] K Sommart, M Wanapat, P Rowlinson, DS Parker, P Climee and S Panishying. The use of casava chip as an energy source for lactating dairy cows fed rice straw. In: Proceedings of the British Society of Animal Science. Penicuik, Scotland, 2000, p. 1094-101.

[4] JR Aschenbach, GB Penner, F Stumpff and G Gabel. Ruminant nutrition symposium: Role of fermentation acid absorption in the regulation of ruminal pH. J. Anim. Sci. 2011; 89, 1092-107.

[5] BU Metzler-Zebeli, M Hollmann, S Sabitzer, L Podstatzky-Lichtenstein, D Klein and Q Zebeli. Epithelial response to high-grain diets involves alteration in nutrient transporters and $\mathrm{Na}+/ \mathrm{K}+-$ ATPase mRNA expression in rumen and colon of goats. J. Anim. Sci. 2013; 91, 4256-66.

[6] D Kathrin, K Annabella and Q Zebeli. Peculiarities of enhancing resistant starch in ruminant using chemical methods: Opportunities and challenges. Nutrients 2013; 5, 1970-88.

[7] A Matthe, P Lebzien and G Flachowsky. On the relevance of by-pass starch for the glucose supply of high-yielding dairy cows. Uebersichten zur Tierernaehrung 2000; 28, 1-64.

[8] JT Throckmorton and RA Lengs. Effect of bypass protein or bypass starch on milk yield and body weight grain in grazing dairy. Anim. Prod. Aust. 1984; 15, 628-30.

[9] M Dehghan-Banadaky, R Corbett and M Oba. Effects of barley grain processing on productivity of cattle. J. Anim. Feed Sci. Technol. 2007; 137, 1-24.

[10] JS Shen, LJ Song, HZ Sun, B Wang, Z Chai, B Chacher and JX Liu. Effects of corn and soybean meal types on rumen fermentation, nitrogen metabolism and productivity in dairy cows. J. Anim. Sci. 2015; 28, 351-9.

[11] CB Theurer, GB Huntington, JT Huber, RS Swingle and JA Moore. Net absorption and utilization of nitrogenous compounds across ruminal, intestinal, and hepatic tissues of growing beef steers fed dry-rolled or steam flaked sorghum grain. J. Anim. Sci. 2001; 80, 525-32.

[12] XP Martínez, MR Sánchez, J López, EVA Manjarrez, EG Padilla and HRV Ávila. Follicular development and ovulation rate in Creole goats after short-term consumption of wheat protected from ruminal degradation. Tecnica Pecuaria en Mexico 2008; 46, 449-62.

[13] C Wachirapakorn, A Cherdthong, W polviset and W Srakaew. 2018, Producing of modified high bypass starch improving energy utilization to use as by-pass energy source in high quality fattening beef cattle diet. Project Report, Khon Kaen University, Khon Kaen, Thailand.

[14] P Zhang, RL Whistler, RL BeMiller and BR Hamaker. Banana starch: Production, physicochemical properties, and digestibility - A review. Carbohydr. Polymer. 2005; 59, 443-58.

[15] MD Elizabeth. 2013, Interactive effects of bulk density of steam flake corn and concentration of sweet bran wet corn gluten feed on feedlot cattle performance, carcass characteristics, and apparent total tract nutrient digestibility. Ph.D. Dissertation. Texas Tech University, Texas, USA.

[16] S De Campeneere, JL De Boever, DL De Brabander. Comparison of rolled, $\mathrm{NaOH}$ treated and ensiled wheat grain in dairy cattle diets. Livest. Sci. 2006; 99, 267-76.

[17] LE Harris, LC Kearl and PV Fonnesbeck. Use of regression equations in predicting availability of energy and protein. J. Anim. Sci. 1972; 35, 658-80. 
[18] AOAC and W Horwitz. Association of Official Analytical Chemists International (AOAC). $17^{\text {th }}$ ed. AOAC International, Gaithersburg, MD, 2000.

[19] PJ Van Soest, JB Robertson and BA Lewis. Methods for dietary fiber neutral detergent fiber, and nonstarch polysaccharides in relation to animal nutrition. J. Dairy Sci. 1991; 74, 3583-97.

[20] JVV Keulen and BA Young. Evaluation of acid insoluble ash as a natural marker in ruminant digestibility studies. J. Anim. Sci. 1977; 44, 282-7.

[21] JM Bremner and DR Keeney. Steam distillation methods of determination of ammonium, nitrate and nitrite. Anal. Chem. Acta. 1965; 32, 218-25.

[22] S Mathew, S Sagathevan, J Thomas and G Mathen. An HPLC method for estimation of volatile fatty acids of ruminal fluid. Indian J. Anim. Sci. 1997; 67, 805-7.

[23] CL Crocker. Rapid determination of urea nitrogen in serum or plasma without deproteinization. Am. J. Med. Technol. 1967; 33, 361-5.

[24] SAS. User's guide: Statistic, Version 6. $12^{\text {th }}$ eds. SAS Institute, North Carolina, 1998.

[25] RGD Steel and JH Torrie. Analysis of covariance. In: RGD Steel and JH Torrie (Eds.). Principles and procedures of statistics: A biometrical approach. McGraw-Hill, New York, 1980, p. 401-37.

[26] NRC. National research council Nutrient requirement of beef cattle. $70^{\text {th }}$ eds. The National Academics Press, Washington, DC, 2000.

[27] K Schmidt, PJ Cowen, CJ Harmer, G Tzortzis, S Errington and PW Burnet. Prebiotic intake reduces the waking cortisol response and alters emotional bias in healthy volunteers. Psychopharmacology 2015; 232, 1793-801.

[28] JE Nocek JE and S Tamminga. Site and digestion of starch in the gastrointestinal tract of dairy cows and its effect on milk yield and composition. J. Dairy Sci. 1991; 74, 3598-629.

[29] JL Firkins. Maximizing microbial protein-synthesis in the rumen. J. Nutr. 1996; 126, 1347-54.

[30] M Wanapat and O Pimpa. Effect of ruminal NH3-N levels on ruminal fermentation, purine derivatives, digestibility and rice straw intake in swamp buffaloes. Asian Aust. J. Anim. Sci. 1999; 12, 904-7.

[31] Br-Corte. Nutrient requirements of zebu and crossbred cattle. $3^{\text {rd }}$ ed. Viçosa (MG): UFV, DZO. 2016 , p. 314.

[32] GB Huntington. Starch utilization by ruminants: From basics to the bunk. J. Anim. Sci. 1997; 75, 852-67.

[33] BH Gulmez and II Turkmen. Effect of starch sources with different degradation rates on ruminal fermentation of lactating dairy cows. Revue. Méd. Vét. 2007; 158, 92-9.

[34] S Khampa and M Wanapat. Influences of energy sources and levels supplementation on ruminal fermentation and microbial protein synthesis in dairy steers. Pakistan J. Nutr. 2006; 5, 294-300.

[35] GB Huntington, DL Harmon and CJ Richards. Sites, rates, and limits of starch digestion and glucose metabolism in growing cattle. J. Anim. Sci. 2006; 84, 14-24.

[36] WZ Yang, KA Beauchemin and LM Rode. Effects of grain processing, forage to concentrate ratio, and forage particle size on rumen $\mathrm{pH}$ and digestion by dairy cows. J. Dairy Sci. 2001; 84, 2203-16.

[37] MA Mcniven, MR Weisbjerg and $T$ Hvelplund. Influence of roasting or sodium hydroxide treatment of barley on digestion in lactating cows. J. Dairy Sci. 1995; 78, 1106-15.

[38] ER Ørskov and IM Donald. The estimation of protein degradability in the rumen from incubation measurements weighted according to rate of passage. J. Agri.Sci. 1979; 92, 499-503.

[39] DH Wasserman. Four grams of glucose. Am. J. Physiol. Endo. Met. 2009; 296, 11-21.

[40] JJ Kaneko. Carbohydrate metabolism and its disorders: Clinical biochemistry of domestic animals. $3^{\text {rd }}$ eds. Academic Press, New York, 1980.

[41] A Lehninger, D Nelson and M Cox. Lehninger Principles of Biochemistry. $7^{\text {th }}$ eds. Macmillan Higher Education, Basingstoke, New York, 2017.

[42] JP Warade. Fasting blood glucose level higher than post-meal in healthy subjects: A study of 738 subjects. World J. Pharmaceut. Res. 2014; 3, 1121-8.

[43] E Norberg, H Volden and OM Harstad. Technical note: Assessment of recovery site of mobile nylon bags for measuring ileal digestibility of starch in dairy cows. J. Dairy Sci. 2007; 90, 418-21. 
http://wjst.wu.ac.th

[44] P Chanjula, W Ngampongsai and M Wanapat. Effects of replacing ground corn with cassava chip in concentrate on feed intake, nutrient utilization, rumen fermentation characteristics and microbial populations in goats. Asian. Aust. J. Anim. Sci. 2007; 20, 1557-66.

[45] CS Mayne and JG Doherty. The effect of fine grinding or sodium hydroxide treatment of wheat, offered as part of a concentrate supplement, on the performance of lactating dairy cows. J. Anim. Sci. 1996; 63, 11-9.

[46] RH Phipps, JD Sutton, DJ Humphries and AK Jones. A comparison of the effects of cracked wheat and sodium hydroxide-treated wheat on food intake, milk production and rumen digestion in dairy cows given maize silage diets. J. Anim. Sci. 2001; 72, 585-94. 